\title{
Escape room in education: a bibliometric study
}

\author{
Diana Marín Suelves, María Isabel Vidal Esteve, M. Isabel Pardo Baldoví \\ Department de Didàctica i Organització Escolar, Universitat de València, Spain.
}

\begin{abstract}
The impact of technologies in all areas is one of the main points that characterize the current society. In the educational context, recently, great efforts are being made to adapt the system to characteristics and needs of the students of the 21st century. Gamification in education consist on the use of structures, characteristics, dynamics and aesthetics of games for educational purposes, to increase students participation and motivation. The escape room is a gamified activity in which one or more teams must leave a place during a limited time solving a challenge whose goal is learning. This study pretends to analyze research trends through a bibliometric study of scientific production deposited in Scopus. 32 articles were obtained for the analysis. The results indicate an increase in scientific publications in last decade, and the main mean of dissemination are journals, specially in Social Sciences field. In addition, data shows the low impact and the absence of medium and large producers. Finally, the weight of Spain highlights and the implementation of escape rooms in the Higher Education stage stands ou too.
\end{abstract}

Keywords: Bibliometrics; Gamification; Escape room, Education, Motivation, Breakout. 


\section{Introduction}

One of the main changes of recent times has been the introduction of technologies in classrooms. This reality has led changes in teaching practices, leading to different methodologies. Gamification is one of them. According to Deterding, Khaled, Nacke \& Dixon (2011) is not a term on which there is consensus, although it is accepted that it involves the introduction of gaming elements to motivate students and get implication in their learning. In recent times, gamification has been applied in different educational contexts and stages (Corchuelo, 2018; Fernández, Prieto, Alcaraz, Sánchez \& Grimaldi, 2018; Manzano \& Baeza, 2018; Martínez, 2017; Pintor, 2017) and in students with functional diversity, specifically in intellectual disability (Vidal, López, Marín \& Peirats, 2018), obtaining the improvement of autonomy and inclusion, and the development of communicative and social skills, as a result. Within this framework, in recent years, escape room activities have begun to be applied in the educational field, and in order to know the real impact obtained from its use, we carried out the following research.

In order to study this issue, a bibliometric analysis of the trends of scientific production has been carried out. Some of the questions that are intended to be answered are: Is there scientific research on the implementation of escape room in education? What bibliometric behaviour do these publications have? What countries stand out in the literature? What place does Spain occupy? And what is the impact of these publications?

The starting hypothesis is that gamified strategies applied to education from playful activities such as escape rooms, allow the achievement of learning and the adjustment to the characteristics of students of the 21 st century.

\section{Method}

Bibliometry allows quantifying scientific activity on an object of study (Tomás \& Tomás, 2018), in this case, on the applications of the escape room to the educational field.

The scientific production deposited in the Scopus database was used, for being the most complete in temporary coverage, for the number of documents (Hernández, Sans, Jové \& Reverter, 2016) and for its scientific prestige.

For the search of the documents to analysis, the words: escape room OR breakout AND school OR education were used as keywords in title or summary. No time or language limits were used an the 32 documents obtained in the search were relevant for this study.

The data analysis was performed according to productivity variables and thematic relational nodes. For the graphical representation of the results, co-occurrence maps were made with fractional counting through Vosviewer tool (Van Eck \& Waltman, 2010). 


\section{Results}

The results of this bibliometric study are grouped around productivity and content analysis.

Regarding the variables involved in productivity, the data are differentiated according to typologies, area of knowledge and temporality; authors and countries; and impact.

\subsection{Analysis of the type of documents, area and temporality}

First, according to the number of documents resulting in the search, low figures stand out, despite we don't have applied any temporary filters.

Regarding the type of documents of the 32 resulting documents analyzed, the majority (75\%) are scientific articles, followed by conferences (19\%), and book chapters or notes (3\% respectively).

In regard to the area from which these works are carried out, Social Sciences (33\%) stand out, followed by others as chemistry $(9 \%)$, engineering (7\%), nursing (7\%) or mathematics (3\%), among others.

Regarding temporal distribution of scientific productivity, we present the data of documents published per year, it allows to know the frequency of publication on this issue, the interest in this object of study, and the diachronic tendency; and in this case, results only appear stands out only in the last decade. In Figure 1, the number of documents published between 2011 and 2019 is presented, although it is considered that it was in 2016 when the use of this term began in Europe. As it can be seen, the number of publications has increased in recent years, especially since 2017 .

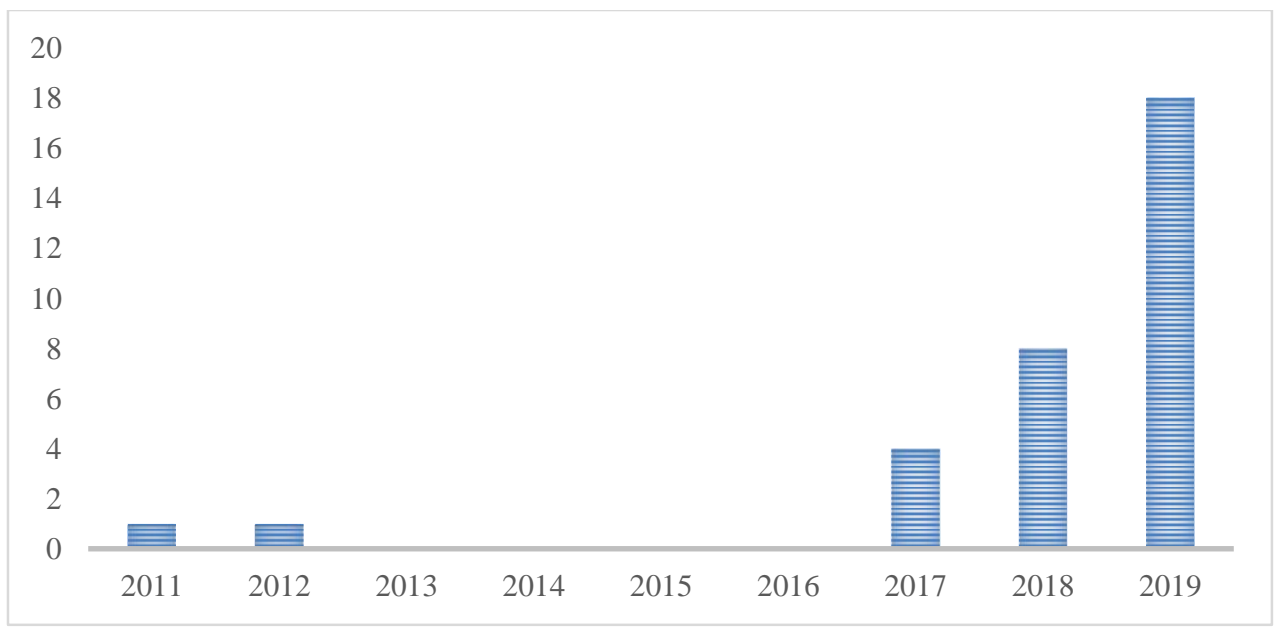

Figure 1. Number of items per year. Source: Own elaboration from Scopus. 


\subsection{Analysis of authors and countries}

In regard to collaboration and co-authorship, there are an amount of 119 signatory authors of the 32 selected articles, therefore, in this field the rate of collaboration is high. Table 1 shows the results according to the number of signatory authors in each article, which allows us to know the collaboration networks generated in the scientific community regarding the use of escape rooms in education.

Table 1. Collaboration and co-authorship

\begin{tabular}{ccc}
\hline Authors & $\mathbf{N}$ & $\%$ \\
\hline One & 5 & $15 \%$ \\
& & \\
\hline Two & 5 & $15 \%$ \\
& & \\
\hline Three & 6 & $19 \%$ \\
\hline Four & 7 & $22 \%$ \\
\hline Five & 3 & $9 \%$ \\
& & \\
\hline More than 5 & 6 & $19 \%$ \\
\hline \multicolumn{2}{l}{ Source: Own elaboration. }
\end{tabular}

On the one hand, as observed, most articles were written in collaboration (85\%). Half of the documents were written by more than four authors, highlighting the work of FerreiroGonzález, Amores-Arrocha, Espada-Bellido, Aliano-Gonzalez, Vázquez-Espinosa, González De Peredo, ... \& Cejudo-Bastante (2019) with a total of 10 authors. On the other hand, the distribution of the production is described based on the number of works signed by the same author, based on Lotka's scientific productivity law. Compared to other recent studies focused on the analysis of gamification (Peirats, Marín \& Vidal, 2019), on the digitalization of curricular contents (Marín, Pardo \& Vidal, 2019) or on the impact of technologies on attention to diversity (Vidal, Marín, Peirats \& Pardo, 2019), only occasional producers (119 authors) are found in this case, with only one document in the field. 




Figure 2. Publications by country. Source: Own elaboration from Scopus.

Furthermore, regarding the bibliometric size of each country (Figure 2), there are great differences, highlighting the United States with 12 documents; Spain with 5 documents (Borrego, Fernández, Blanes \& Robles, 2017; Ferreiro-González, et al., 2019; GómezUrquiza, Gómez-Salgado, Albendín-García, Correa-Rodríguez, González-Jiménez \& Cañadas-De la Fuente, 2019; Lopez-Pernas, Gordillo, Barra \& Quemada, 2019; Santos, Miguel, Queiruga-Dios \& Encinas, 2019), United Kingdom with 3 and Canada with 2, in addition, a total of 10 countries only have one article.

\subsection{Impact analysis}

Regarding the impact of the articles analyzed, counted through the number of citations received, it stand out that $34 \%$ do not have any citation and $47 \%$ have between one and five citations. These data reflects the low impact of most jobs among the scientific community. However, there are three articles with more than ten citations (Borrego, Fernández, Blanes \& Robles, 2017; Dietrich, 2018; Eukel, Frenzel \& Cernusca, 2017).

\subsection{Content Analysis}

According to the stages in which each investigation is carried out, more than $80 \%$ of the studies analyzed were focus on Higher Education, mainly in the area of future health personnel training, such as in the works from Guckian, Sridhar \& Meggitt (2019), Rosenkrantz, Jensen, Sarmasoglu, Madsen, Eberhard, Ersbøll \& Dieckmann (2019), or Gómez-Urquiza, et al. (2019).

In terms of benefits obtained by the participating students, we can highlight the promotion of communication and group dynamics, the increase in commitment and attention or problem-solving skills (Ross \& Bell, 2019), the improvement of learning (Berthod, 
Bouchoud, Grossrieder, Falaschi, Senhaji \& Bonnabry, 2019; Franco \& DeLuca, 2019; Novak, Lozos \& Spear, 2019) or student motivation too (Kinio, Dufresne, Brandys \& Jetty, 2019). Likewise, the potential of this activity is affirmed as an innovative educational tool (Ferreiro-González, et al., 2019).

Finally, regarding the content, we have analyze the most frequent keywords and we have group toghether them into categories that emerge from the reading. Analysing the keywords, the high diversity of them stands out, we could find 160 different keywords in only 32 documents. The most frequent keywords in the articles analyzed are: learning, gamification, followed by terms such as students, teaching or curriculum. Figure 3 shows the co-occurrence map of the keywords that reflects the relationships between the terms and the tendency to appear together. Three clusters or thematic relational nodes were distinguished.

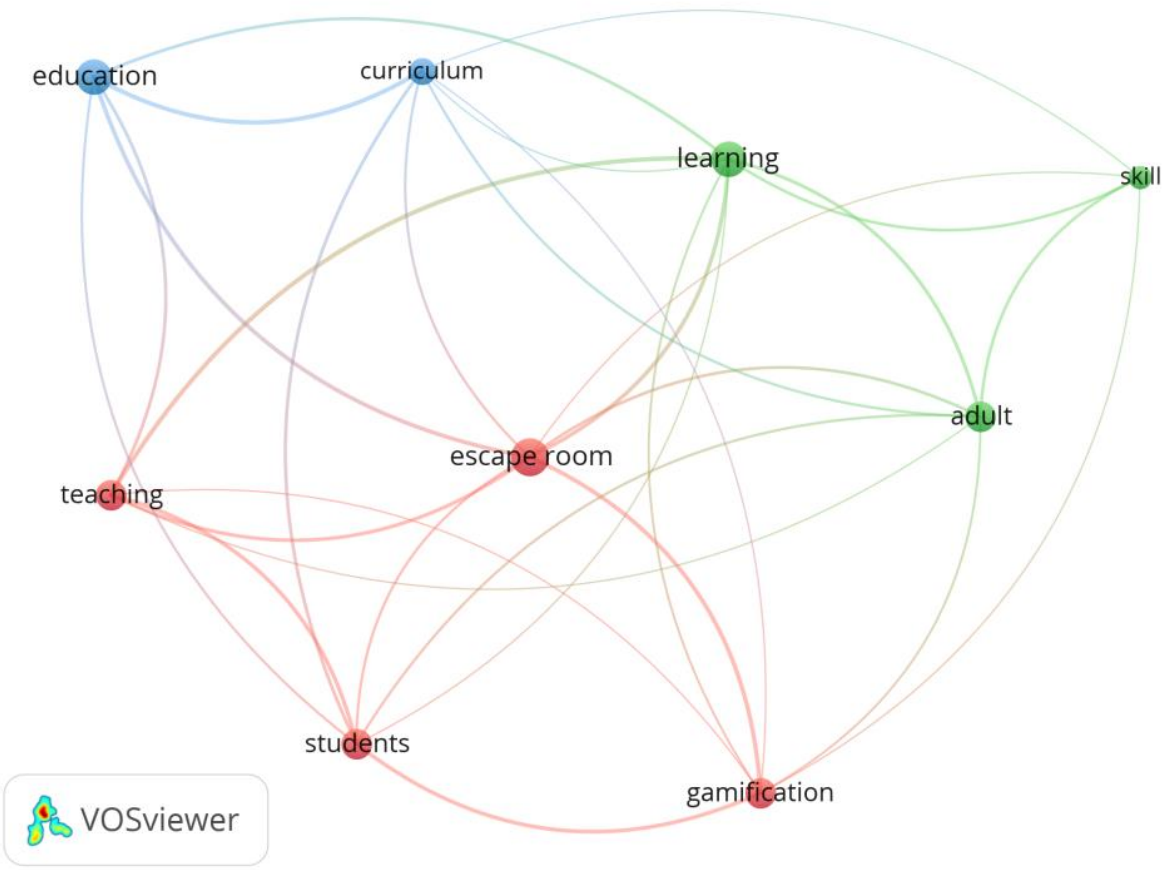

Figure 3. Co-occurrence map of terms. Source: VOSviewer

\section{Conclusions}

The aim of this study was to analyze trends in research regarding the use of escape room activities in educational field. To achieve this objective, a bibliometric analysis of the scientific production available in the Scopus database was carried out, considering the productivity and the content of selected documents. 
We can conclude that many are the possibilities of this activity, because in recent times, despite the small number of publications found, promising results have been obtained for the improvement of education from a paradigm in which the main characters are the students, and the focus, the development of life skills.

Finally, in regard to the lines of future research, it is necessary to reflect on the application of escape room in other educational stages, on the implications that the introduction of this resource will have on teacher training, and finally to compare the results of this analysis with those obtained through other databases such as JCR or WOS.

\section{Financing and acknowledgment}

To Conselleria de Educación, Investigación, Cultura y Deporte for the promotion of scientific research, technological development and innovation in Comunitat Valenciana. This paper is based on the results of phase I of project GV/2018/074.

To Ministerio de Ciencia, Innovación y Universidades by the grant to Formación del Profesorado Universitario.

\section{References}

Aleixandre, R. (2010). Bibliometría e indicadores de producción científica. En J. Jiménez, J.M. Argimon, A. Martín y T. Vilardell (Eds.), Publicación científica biomédica: cómo escribir y publicar un artículo de investigación (p. 363-384). Barcelona: Editorial Elsevier.

*Berthod, F., Bouchoud, L., Grossrieder, F., Falaschi, L., Senhaji, S., \& Bonnabry, P. (2019). Learning good manufacturing practices in an escape room: Validation of a new pedagogical tool. Journal of Oncology Pharmacy Practice, doi:10.1177/1078155219875504

Bordons, M., \& Zulueta, M. (1999). Evaluación de la actividad científica a través de indicadores bibliométricos. Revista española de cardiología, 52(10), 790-800.

*Borrego, C., Fernández, C., Blanes, I., \& Robles, S. (2017). Room escape at class: Escape games activities to facilitate the motivation and learning in computer science. Journal of Technology and Science Education, 7(2), 162-171. doi:10.3926/jotse.247

Corchuelo, C. A. (2018). Gamificación en educación superior: experiencia innovadora para motivar estudiantes y dinamizar contenidos en el aula. Edutec. Revista Electrónica de Tecnología Educativa, 63, 29-41. doi: 10.21556/edutec.2018.63.927

Deterding, S., Khaled, R., Nacke, L. E., \& Dixon, D. (2011, May). Gamification: Toward a definition. En CHI 2011 gamification workshop proceedings (Vol. 12). Vancouver BC, Canada.

*Dietrich, N. (2018). Escape classroom: The leblanc process - an educational "escape game". Journal of Chemical Education, 95(6), 996-999. doi:10.1021/acs.jchemed.7b00690 
*Eukel, H. N., Frenzel, J. E., \& Cernusca, D. (2017). Educational gaming for pharmacy students - design and evaluation of a diabetes-themed escape room. American Journal of Pharmaceutical Education, 81(7) doi:10.5688/ajpe8176265

Fernández, J., Prieto, E., Alcaraz, V., Sánchez, A.J., \& Grimaldi, M. (2018). Aprendizajes significativos mediante la Gamificación a partir del Juego de Rol: "Las Aldeas de la Historia”. Espiral. Cuadernos del Profesorado, 11(22), 69-78.

*Ferreiro-González, M., Amores-Arrocha, A., Espada-Bellido, E., Aliano-Gonzalez, M. J., Vázquez-Espinosa, M., González-De-Peredo, A. V., . . . Cejudo-Bastante, C. (2019). Escape ClassRoom: Can you solve a crime using the analytical process? Journal of Chemical Education, 96(2), 267-273. doi:10.1021/acs.jchemed.8b00601

*Franco, P. F., \& DeLuca, D. A. (2019). Learning through action: Creating and implementing a strategy game to foster innovative thinking in higher education. Simulation and Gaming, 50(1), 23-43. doi:10.1177/1046878118820892

*Frick, J., Slagman, A., Möckel, M., Searle, J., Stemmler, F., Joachim, R., \& Lindner, T. (2018). Erleben von aggressivem Verhalten in der Notaufnahme nach Etablierung eines Deeskalationstrainings: Zweite Mitarbeiterbefragung in den Akutbereichen der Charité - Universitätsmedizin Berlin. Notfall Und Rettungsmedizin, 21(5), 349-356. doi:10.1007/s10049-017-0394-3

*Gómez-Urquiza, J. L., Gómez-Salgado, J., Albendín-García, L., Correa-Rodríguez, M., González-Jiménez, E., \& Cañadas-De la Fuente, G. A. (2019). The impact on nursing students' opinions and motivation of using a "Nursing escape room" as a teaching game: A descriptive study. Nurse Education Today, 72, 73-76. doi:10.1016/j.nedt.2018.10.018

Guckian, J., Sridhar, A., \& Meggitt, S. J. (2019). Exploring the perspectives of dermatology undergraduates with an escape room game. Clinical and Experimental Dermatology, doi:10.1111/ced.14039

Hernández, V., Sans, N., Jové, M. C., \& Reverter, J. (2016). Comparación entre Web of Science y Scopus, estudio bibliométrico de las revistas de anatomía y morfología. International Journal of Morphology, 34(4), 1369-1377.

*Kinio, A. E., Dufresne, L., Brandys, T., \& Jetty, P. (2019). Break out of the classroom: The use of escape rooms as an alternative teaching strategy in surgical education. Journal of Surgical Education, 76(1), 134-139. doi:10.1016/j.jsurg.2018.06.030

*Lopez-Pernas, S., Gordillo, A., Barra, E., \& Quemada, J. (2019). Examining the use of an educational escape room for teaching programming in a higher education setting. IEEE Access, 7, 31723-31737. doi:10.1109/ACCESS.2019.2902976

Manzano, A.P. \& Baeza, J.A. (2018). Gamificación transmedia para la divulgación científica y el fomento de vocaciones procientíficas en adolescentes. Comunicar, 55, 93103.

Marín, D., Pardo, M.I., \& Vidal, I. (2019, March). Digitalización de contenidos curriculares. Un análisis bibliométrico. In Conference Proceedings EDUNOVATIC 2018: 3rd Virtual International Conference on Education, Innovation and ICT (p. 215). Adaya Press. 
Martínez, J. (2017). Gamificando el huerto escolar en Educación Primaria. Los superhéroes al rescate. Actas del III Congreso Internacional de Educación Mediática y Competencia Digital.

*Novak, J., Lozos, J. C., \& Spear, S. E. (2019). Development of an interactive escape room intervention to educate college students about earthquake preparedness. Natural Hazards Review, 20(1) doi:10.1061/(ASCE)NH.1527-6996.0000322

Peirats, J., Marín, D., \& Vidal, M. I. (2019). Bibliometría aplicada a la gamificación como estrategia digital de aprendizaje. RED, 19(60), 1-26.

Pintor, P. (2017). Gamificando con Kahoot! en evaluación formativa. Infancia, Educación y Aprendizaje (IEYA), 3(2), 112-117.

*Rosenkrantz, O., Jensen, T. W., Sarmasoglu, S., Madsen, S., Eberhard, K., Ersbøll, A. K., \& Dieckmann, P. (2019). Priming healthcare students on the importance of nontechnical skills in healthcare: How to set up a medical escape room game experience. Medical Teacher, 41(11), 1285-1292. doi:10.1080/0142159X.2019.1636953

Ross, R., \& Bell, C. (2019). Turning the classroom into an escape room with decoder hardware to increase student engagement. Paper presented at the IEEE Conference on Computatonal Intelligence and Games, CIG, 2019-August doi:10.1109/CIG.2019.8848020

*Santos, M. J., Miguel, M., Queiruga-Dios, A., \& Encinas, A. H. (2019). Looking for the antidote for contaminated water: Learning through an escape game doi:10.1007/978-3030-20005-3_22

Tomás-Górriz, V., \& Tomás-Casterá, V. (2018). La Bibliometría en la evaluación de la actividad científica. Hospital a Domicilio, 2(4), 145-163.

Van Eck, N. J., \& Waltman, L. (2011). Text mining and visualization using VOSviewer. arXiv preprint arXiv:1109.2058.

Vidal, M. I., López, M., Marín, D., \& Peirats, J. (2018). Revisión y análisis de investigación publicada sobre intervención gamificada en discapacidad intelectual.Etic@net, 2(18),274-297.

Vidal, M. I., Marín, D., Peirats, J., \& Pardo, M. I. (2019, July). Technologies for attention to diversity: a bibliometric study. In HEAD'19. 5th International Conference on Higher Education Advances (973-981). Editorial Universitat Politècnica de València. doi: 10.4995/HEAD19.2019.9126

* References marked with an asterisk correspond to those that have been used in the bibliometric analysis. 